\title{
Development of PCR-ELISA for Detection and Differentiation of Didymella bryoniae from Related Phoma species
}

\author{
B. M. Somai and A. P. Keinath, Department of Plant Pathology and Physiology, Clemson University, Clemson, SC \\ 29634; and R. A. Dean, North Carolina State University, Fungal Genomics Laboratory, Raleigh 27695
}

\begin{abstract}
Somai, B. M., Keinath, A. P., and Dean, R. A. 2002. Development of PCR-ELISA for detection and differentiation of Didymella bryoniae from related Phoma species. Plant Dis. 86:710-716.

The causal agent of gummy stem blight, Didymella bryoniae, often is isolated from infected cucurbits together with other Phoma spp. Polymerase chain reaction (PCR) primers specific to D. bryoniae and Phoma were used to develop and evaluate a microtiter-based PCR-enzymelinked immunosorbent assay (ELISA) technique. Primers were modified by addition of a fluorescein and a biotin label to the $5^{\prime}$ ends of the forward and reverse primers, respectively. After amplification, PCR products were detected in an ELISA using horseradish peroxidaseconjugated antifluorescein antibody and three substrates that yielded three colored products, one for each fungal group. The most sensitive substrate (highest signal:noise ratio) was $2,2^{\prime}$-azinobis[3-ethylbenz-thiazoline-6-sulfonic acid]. PCR-ELISA successfully detected 45 of $46 \mathrm{D}$. bryoniae and all 13 Phoma isolates that were used. Results were comparable to those obtained with gel electrophoresis. Only one D. bryoniae isolate could not be detected with PCR-ELISA; this isolate also produced a fragment larger than other $D$. bryoniae isolates on agarose gels. PCRELISA was used successfully on crude extracts of "blind" fungal samples and identified seven of seven isolates as D. bryoniae or Phoma. Although less sensitive than gel electrophoresis, PCR-ELISA was a highly specific, yet simple, rapid and convenient assay for detection of $D$. bryoniae and Phoma sp.
\end{abstract}

Gummy stem blight (GSB), is a major disease limiting production of cantaloupe (Cucumis melo L.), cucumber (Cucumis sativus L.), and watermelon (Citrullus lanatus (Thunb.) Matsum. \& Nakai) in the southern United States $(19,20,29,33)$. The pathogen that causes GSB is Didymella bryoniae (Auersw.) Rehm (anamorph: Phoma cucurbitacearum (Fr.:Fr.) Sacc.). The fungus can infect stems, leaves, and fruit; the disease on fruit is referred to as black rot (39). Symptoms include seedling death, leaf spots, stem cankers, rapid blighting, and fruit rot $(29,39)$. GSB has become more economically important as genetic and chemical control of other cucurbit diseases has become more effective $(28,35)$. In addition, because transplants

Corresponding author: A. P. Keinath

E-mail: tknth@clemson.edu

Current address of B. M. Somai: Department of Microbiology, University of Durban-Westville, Private Bag X54001, Natal, South Africa.

Technical contribution 4497 of Agriculture and Forestry Research, Clemson University, Clemson, South Carolina.

Accepted for publication 17 March 2002.

Publication no. D-2002-0521-01R

(C) 2002 The American Phytopathological Society are used widely now in cucurbit production, $D$. bryoniae from contaminated seed causes GSB on seedlings in greenhouse transplant production facilities $(7,11,12)$.

Several Phoma species other than P. cucurbitacearum have been recovered from cucurbit seedlings and mature plants exhibiting GSB symptoms (6-8). Phoma spp. also occur on cucurbit seeds at low frequencies, $\leq 0.1 \%$ in one study (6). D. bryoniae can be differentiated from related Phoma species by carefully examining colony morphology and the shape of conidia, measuring colony growth rate and conidial dimensions, inducing production of pseudothecia, and conducting pathogenicity assays on seedlings (8). However, some isolates of $D$. byroniae do not produce pycnidia or pseudothecia in culture (1,39). Random amplified polymorphic DNA (RAPD) fingerprinting (8), and more recently a polymerase chain reaction (PCR)-based diagnostic technique $(9,30$, 32,40 ) have been used for more reliable identification of the GSB pathogen. Using RAPD profiles and PCR primers, two genotypes of $D$. bryoniae have been differentiated from each other and from nonpathogenic or weakly virulent Phoma spp. $(8,31,32,40)$. The two genotypes, although both pathogenic, differ in virulence to a variety of cucurbits $(31,40)$. The less virulent genotype, RAPD Group (RG) II, was recovered more frequently than the more virulent genotype, RG I, in New York (40), but with two exceptions, has not been found in other states (30).

PCR with specific primers has been the most accurate and reliable method currently available to identify pathogens. However, visualization of PCR products is usually performed by electrophoresis in agarose gels followed by staining with ethidium bromide or other fluorescent dyes. The drawback of electrophoretic techniques is that the procedure becomes labor-intensive and limits the number of samples that can be processed simultaneously. PCR-enzyme-linked immunosorbent assay (PCR-ELISA) is a technique that has been used successfully to detect viruses $(10,27)$, bacteria $(4,14,37)$, rickettsias $(3,16)$, phytoplasmas $(22)$, and fungi (18). This method combines the specificity of the PCR reaction with the increased sensitivity of the ELISA reaction. All reactions can be performed in 96-well microtiter plates for mass screening of PCR products. The entire procedure does not require any sophisticated equipment other than a thermal cycler and an ELISA reader, which already may be available in many laboratories. The objective of this study was to develop and evaluate a microtiter-based ELISA system to detect PCR products specific to $D$. bryoniae and Phoma-like fungi isolated from plants with symptoms of GSB.

\section{MATERIALS AND METHODS}

Fungal isolates. A total of 69 isolates of three different, yet closely related, fungal groups originally obtained from cucurbit plants with symptoms of GSB were used for development of the ELISA technique (Table 1). The isolates used in this study were divided into three groups based on RAPD fingerprints, namely the $D$. bryoniae RG I, D. bryoniae RG II (previously referred to as Phoma II), and Phoma groups $(30-32,40)$. Isolates supplied by $\mathrm{T}$. A. Zitter, Cornell University, Ithaca, NY, were referred to as the New York (NY) collection, although some originated from other states within the United States. A. P. Keinath provided other isolates, designated the South Carolina (SC) collection. G. P. Hoyos, Syngenta Seeds, Inc., provided 10 isolates that originated from watermelon seed ("blind" test samples). 
DNA isolation and identity of fungal isolates. All isolates were grown on 0.25 strength potato dextrose agar (QPDA) in the dark at $24^{\circ} \mathrm{C}$ for 1 to 2 weeks. In the dark, few pycnidia are formed. Mycelium scraped from agar plates flooded with $5 \mathrm{ml}$ sterile water was used to seed sucrosecasein-salts medium (15), which was shaken in the dark at room temperature for 3 to 5 days (8). Cultures were snap-frozen in liquid nitrogen and stored at $-80^{\circ} \mathrm{C}$ until used for DNA isolation. DNA was isolated according to a previously described phenol:chloroform procedure (13) and stored in water at $4^{\circ} \mathrm{C}$.

To simulate fungi growing from infected seeds onto filter paper in blotter assays of seed lots (5), isolates were grown on 5-mm filter paper disks on QPDA at $23^{\circ} \mathrm{C}$ with a 12-h photoperiod for 3 to 4 days. Once the disks were covered completely with mycelium but before pycnidia formed, disks were removed from the agar. Crude extracts were prepared immediately by completely macerating mycelium-covered disks in $40 \mu \mathrm{l}$ TPS (100 mM Tris- $\mathrm{HCl}, \mathrm{pH}$ 9.5; $1 \mathrm{M} \mathrm{KCl} ; 10 \mathrm{mM}$ EDTA) isolation buffer (36). The crude extract was incubated at $65^{\circ} \mathrm{C}$ for $20 \mathrm{~min}$, and then centrifuged in a microfuge for $5 \mathrm{~min}$. The supernatant was removed, diluted 1:5 in water, and stored at $4^{\circ} \mathrm{C}$ until used.

Development of specific PCR primers. RAPD fingerprinting of $D$. bryoniae RG I isolate FL2, Phoma isolate NY19, and D. bryoniae RG II isolate AZ1 was performed using 40 decamer oligonucleotide primers (OPK and OPT kits, Operon Technologies, Alameda, CA) as described previously $(8,9,30,31)$. DNA bands were resolved in $1.5 \%$ agarose gels at $6 \mathrm{~V} / \mathrm{cm}$ in $1 \times \mathrm{TAE}$ running buffer ( $40 \mathrm{mM}$ Tris; $20 \mathrm{mM}$ glacial acetic acid; $1 \mathrm{mM}$ EDTA), and blotted onto nylon membranes (Amersham, Arlington Heights, IL) by overnight capillary transfer.

Purified, sheared genomic DNA from $D$. bryoniae RG I isolate FL2 was labeled with ${ }^{32} \mathrm{P}$-dCTP and hybridized to the mem- brane-bound RAPD DNA bands at $65^{\circ} \mathrm{C}$ overnight. Membranes were washed in $1 \times$ SSC $(150 \mathrm{mM} \mathrm{NaCl} ; 15 \mathrm{mM}$ sodium citrate) and $0.1 \%$ sodium dodecyl sulfate (SDS) at $65^{\circ} \mathrm{C}$ for $20 \mathrm{~min}$ and exposed to $\mathrm{X}$-O-Mat autoradiography film at $-80^{\circ} \mathrm{C}$ with intensifying screens. Bands from Phoma NY19 and D. bryoniae RG II AZ1 that did not hybridize with DNA of FL2 were identified. These bands were therefore putatively unique to Phoma and $D$. bryoniae RG II. Membranes were stripped and similarly hybridized with ${ }^{32} \mathrm{P}-\mathrm{dCTP}$ labeled $D$. bryoniae RG II AZ1 genomic DNA to identify DNA fragments unique to D. bryoniae RG I FL2 and Phoma NY19. This was done for all 40 primers to identify RAPD bands unique to D. bryoniae RG I, RG II, or Phoma.

Approximately $0.5 \mu \mathrm{g}$ of genomic DNA from each of two isolates from the $D$. bryoniae RG I (FL2 and C68), Phoma (NY19 and W97), and D. bryoniae RG II (AZ1 and NY16) groups was subjected to restriction digests with 10 to 12 units of BamHI, HindIII, EcoRI and PstI (Promega, Madison, WI) for $16 \mathrm{~h}$ according to the manufacturer's instructions. DNA from all six isolates was subjected to single restriction digests with each enzyme, loaded into $1 \%$ agarose gels, and subjected to electrophoresis at $4 \mathrm{~V} / \mathrm{cm}$ for $6 \mathrm{~h}$. After electrophoresis, the restricted DNA was blotted onto nylon membranes.

RAPD fragments identified by differential hybridization were excised from agarose gels, macerated, frozen at $-80^{\circ} \mathrm{C}$ for $20 \mathrm{~min}$, and then centrifuged in a microcentrifuge for $10 \mathrm{~min}$ (freeze-squeeze). The supernatant containing DNA was removed and stored at $4{ }^{\circ} \mathrm{C}$. Approximately 50 to $100 \mathrm{ng}$ of each RAPD DNA fragment was radiolabeled and hybridized to the restricted genomic DNA. By screening each RAPD fragment identified from the differential RAPD hybridization, unique groupspecific fragments were identified.

The unique group-specific RAPD fragments identified by differential RAPD hybridization were ligated overnight at $4{ }^{\circ} \mathrm{C}$ into the pGem T-easy (Promega) PCR plasmid cloning vector. Ligated DNA was electroporated into electrocompetent $E$. coli (XL1 Blue) cells using a BTX Transfector 100 electroporator (Biotechnologies and Experimental Research, Inc., San Diego, CA) and plated onto Luria-Bertani (LB) plates amended with $100 \mathrm{mg} / \mathrm{liter}$ ampicillin. Plasmid DNA was isolated from the resulting white colonies using the Wizard Plus (Promega) plasmid DNA purification system. Plasmid DNA from the clones was digested with EcoRI to release the cloned inserts that were separated from the vector DNA by gel electrophoresis. The DNA was blotted onto nylon membranes and probed with the appropriate RAPD DNA fragment to identify positive clones.

Plasmid inserts were sequenced both in the forward and reverse directions using the ABI fluorescent dye-terminator cycle sequencing ready reaction kit according to the manufacturer's instructions (Perkin Elmer, Boston, MA). Based on sequence information, 21-mer primers with a GC content of approximately $50 \%$, were designed for amplification of as large a PCR fragment as possible. Primers were synthesized and purified by Integrated DNA Technologies (Coralville, IA). The sequence of the $D$. bryoniae RG I-specific forward primer was TGTCGTTGAC ATCATTCCAG $\mathrm{C}$ and the sequence of the reverse primer was ACCACTCTGC TTAGTATCTG C (9). The sequence of the D. bryoniae RG II forward primer was GCTAAGCCTT AATCTAGCTG $\mathrm{C}$ and sequence of the reverse primer was GAGAGTAAGC TAACCTAAAG G (9). The sequence of the Phoma-specific forward primer was GTCAGAGTTC AGAATGCTTC $G$ and sequence of the reverse primer was ACGGATGAAT AACACGGAAG A (9). The identity of all isolates in the NY and SC collections was confirmed with PCR using these specific primers.

Table 1. Didymella bryoniae and Phoma isolates used for polymerase chain reaction enzyme-linked immunosorbent assay (PCR-ELISA)

\begin{tabular}{llll}
\hline Collection & Identity & Origin & Designation \\
\hline New York (NY) & D. bryoniae RG Iy & Florida & FL1, FL2 \\
& & Wisconsin & WI1 \\
& Nhoma & N. Carolina & NC1, NY2, NY3, NY4, NY5, NY6 \\
& D. bryoniae RG II" & New York & NY18, NY19, NY20, NY21 \\
& & New York & AZ1 \\
& D. bryoniae RG I & South Carolina & C45, C46, C48, C49, C51, C53, C61, C62, C64, C66, C68, C69, C70, C72, \\
& & & C74, C76, C79, C81, C82, W73, W74, W95, W99, W100, W101, W103 \\
South Carolina (SC) & Shoma & Couth Carolina & C55, C63, C65, C67, C73, C75, W97 \\
& D. bryoniae RG I & Unknown & W200, W205, W206, W207, W208 \\
& Phoma & Unknown & W202 \\
& $\begin{array}{l}\text { D. bryoniae } \text { RG II } \\
\text { Unknown }\end{array}$ & Unknown & W201 \\
& Unknown & W203, W204, W209 \\
\hline
\end{tabular}

${ }^{\mathrm{y}}$ RAPD Group I and II are distinguished by random amplified polymorphic DNA fingerprints.

${ }^{\text {z }}$ Samples were treated as a "blind" test because their identities were not known prior to the PCR-ELISA assay. However, the identity of each was later independently confirmed by examination of colony and spore morphologies. 
Modification of primers and PCR conditions. The three specific primer pairs used for PCR detection were modified specifically for PCR-ELISA. The 5' end of each of the forward primers was chemically linked to a single biotin moiety while the $5^{\prime}$ end of each of the reverse primers was chemically linked to a single fluorescein moiety. Primer synthesis, chemical modifications, and subsequent polyacrylamide gel purification of all primers were performed by Integrated DNA Technologies (Coralville, IA).

PCR reaction mixtures contained $25 \mu \mathrm{g}$ bovine serum albumin (BSA, New England Biolabs, Beverly, MA), $2.5 \mu$ of $10 \times$ reaction buffer, $1.9 \mathrm{mM} \mathrm{MgCl} 2,0.1 \mathrm{mM}$ deoxynucleotide triphosphates, 1.5 units of Taq DNA polymerase (Promega) and $40 \mathrm{ng}$ template DNA. For amplification of $D$. bryoniae RG I, primers were used at a concentration of $10 \mathrm{ng}$, whereas for amplification of Phoma and D. bryoniae RGII, $40 \mathrm{ng}$ of primers were used. Final PCR reaction volumes were either $25 \mu$ or were increased to $50 \mu \mathrm{l}$ by scaling up the amount of PCR reagents. All tubes were overlaid with two drops of mineral oil before amplification was performed in a Perkin-ElmerCetus (Norwalk, CT) thermal cycler. Thermal cycling conditions were an initial denaturation at $94^{\circ} \mathrm{C}$ for $1 \mathrm{~min}$, followed by 30 cycles of denaturation at $94^{\circ} \mathrm{C}$ for 1 min, annealing at $64^{\circ} \mathrm{C}$ for $1 \mathrm{~min}$, and extension at $72^{\circ} \mathrm{C}$ for $2 \mathrm{~min}$. At the end of 30 cycles, a final extension at $72^{\circ} \mathrm{C}$ for $10 \mathrm{~min}$ was performed before samples were held at $4^{\circ} \mathrm{C}$ until use. Amplification conditions for crude fungal DNA were as described above except that $10 \mathrm{ng}$ of each of the $D$. bryoniae RG I primers and $20 \mathrm{ng}$ of each of Phoma and D. bryoniae RG II primers were used. Primer annealing was performed at $61^{\circ} \mathrm{C}$ for 30 cycles.

Attachment of PCR products and binding of antibody. The wells of neutravidin-coated microtiter plates (Pierce, Rockford, IL) were first washed twice with $200 \mu \mathrm{l}$ phosphate buffered saline $(2.8 \mathrm{mM}$ $\mathrm{NaH}_{2} \mathrm{PO}_{4} ; 3.8 \mathrm{mM} \mathrm{Na} \mathrm{HPO}_{4} ; 145 \mathrm{mM}$ $\mathrm{NaCl}, \mathrm{pH}$ 7.2) supplemented with $0.5 \%$ Tween-20 (PBS/T). After discarding the wash buffer, excess liquid was removed by blotting the plates onto paper towels. Ten microliters of TE (10 mM Tris- $\mathrm{HCl} ; 1 \mathrm{mM}$ EDTA) and $10 \mu \mathrm{l}$ of each PCR product were added into individual wells and mixed by repeated pipetting. The mixture was incubated at ambient temperature for 30 min to allow the DNA to become attached to the neutravidin via the biotin moiety of the forward primers. Excess unbound DNA was washed off with four consecutive washes using $200 \mu \mathrm{lBS} / \mathrm{T}$. Between washes the PBS/T was allowed to remain in the wells for $3 \mathrm{~min}$.

After the final wash, the buffer was discarded, and excess liquid was removed by blotting. Thereafter, $100 \mu \mathrm{l}$ of 1:2,000 diluted horseradish peroxidase (HRP)- conjugated antifluorescein monoclonal antibody (Chemicon, Temecula, CA) was added to each well and incubated for a further $30 \mathrm{~min}$ at room temperature. This allowed the antibody to become attached to the immobilized PCR product via the fluorescein moiety of the reverse primers. HRP-conjugated antibody was diluted in phosphate buffer $\left(13.6 \mathrm{mM} \mathrm{NaH} \mathrm{PO}_{4} ; 2.1\right.$ $\mathrm{mM} \mathrm{Na} \mathrm{HPO}_{4}, \mathrm{pH}$ 7.0) supplemented with $100 \mu \mathrm{g} / \mathrm{ml}$ BSA. Excess antibody was washed off with four consecutive washes using $200 \mu \mathrm{lBS} / \mathrm{T}$ as before and excess buffer was blotted off.

For PCR products derived from crude fungal extracts, the procedure was essentially as above with the following exceptions. After PCR amplification, the DNA was mixed with diethyldithiocarbamic acid (DIECA, Sigma, St. Louis, MO) to a final concentration of $50 \mathrm{mM}(17,25)$. The DNA from $20 \mu \mathrm{l}$ of the samples was bound to microtiter plates. The HRP-conjugated antibody was diluted in phosphate buffer supplemented with $2 \mathrm{mg} / \mathrm{ml}$ BSA. Only 50 $\mu \mathrm{l}$ of HRP-conjugated antibody per well was used.

Color development. PCR products attached to microtiter wells were then detected via the HRP bound to the DNA. For detection of D. bryoniae RG I, Phoma, and D. bryoniae RG II DNA, 3,3,5,5'- tetramethylbenzidine (TMB, Sigma), o-phenylenediamine (OPD, Sigma) and 2,2'-azinobis[3-ethylbenz-thiazoline-6-sulfonic acid] (ABTS, Sigma), respectively, were used. TMB was diluted in citrate buffer $(0.5 \mathrm{M}$ citric acid; $0.5 \mathrm{M}$ sodium citrate, $\mathrm{pH}$ 5), OPD in OPD buffer (27.23 mM Na $2 \mathrm{HPO}_{4}$; $26.84 \mathrm{mM}$ citric acid monohydrate, $\mathrm{pH} 5$ ) and ABTS in citrate buffer, $\mathrm{pH}$ 4.2. The final concentration of all substrates used for detection was $0.5 \mathrm{mg} / \mathrm{ml}$. The three substrates were supplemented with different concentrations of $\mathrm{H}_{2} \mathrm{O}_{2}$ to optimize the color reactions. For TMB, $0.5 \mu \mathrm{l} / \mathrm{ml}$ of $1 \%$ $\mathrm{H}_{2} \mathrm{O}_{2}$ was used whereas for OPD and ABTS, $0.4 \mu \mathrm{l} / \mathrm{ml}$ and $0.5 \mu \mathrm{l} / \mathrm{ml}$ of $30 \%$ $\mathrm{H}_{2} \mathrm{O}_{2}$, respectively, was used. All plates were incubated for $15 \mathrm{~min}$ in the dark at room temperature to promote color development. Thereafter, all reactions were terminated with either $10 \%$ SDS or $3 \mathrm{M}$ sulfuric acid $\left(\mathrm{H}_{2} \mathrm{SO}_{4}\right)$. Absorbance values were immediately read in a Molecular Devices Emax reader (Molecular Devices, Sunnyvale, CA) set to 405-nm wavelength. The entire PCR-ELISA procedure was performed twice with purified DNA and three times with crude fungal extracts.

To determine which ELISA reaction termination reagent gave optimal color development, PCR amplification of three representative isolates of $D$. bryoniae RG I (FL2), Phoma (NY19), and D. bryoniae RG II (AZ1), i.e., one each from the three fungal groups, was performed as described for purified fungal DNA. Each PCR reaction was divided into three aliquots and each aliquot was subjected to PCR-ELISA detection as above. Each aliquot was terminated with $10 \%$ SDS, $0.5 \mathrm{M} \mathrm{H}_{2} \mathrm{SO}_{4}$ or 3 $\mathrm{M} \mathrm{H}_{2} \mathrm{SO}_{4}$. Absorbance values were read in an ELISA reader immediately and thereafter at 15 -min intervals over a 2 -h period.

To confirm the presence of amplified DNA, either $10 \mu \mathrm{l}$ (purified DNA template) or $20 \mu \mathrm{l}$ (crude fungal template) amplification products were loaded on $1 \%$ agarose gels containing ethidium bromide. Electrophoresis was run at $6 \mathrm{~V} / \mathrm{cm}$ for $1 \mathrm{~h}$ in $1 \times$ TAE (40 mM Tris; $20 \mathrm{mM}$ glacial acetic acid; 1 mM EDTA) running buffer. Results for electrophoresis were then compared to those for the PCR-ELISA.

Optimum enzyme concentration. Since the HRP used in this study was uncharacterized in terms of enzyme activity, appropriate dilutions had to be made in order to determine the optimal enzyme concentration that would reproducibly yield the highest signal to noise ratio $(\mathrm{S}: \mathrm{N})$, i.e., positive reaction:negative reaction. Dilutions of the HRP-conjugate, $1: 250,1: 500,1: 2,000$ and 1:4,000, were first made in phosphate buffer supplemented with BSA. One representative isolate (D. bryoniae RG I FL2, Phoma NY19, and D. bryoniae RG II AZ1) from each of the three fungal groups was chosen and each isolate subjected to PCR using all three primer pairs. After PCR amplification, each reaction was divided into four aliquots of $5 \mu \mathrm{l}$ each and mixed with $5 \mu \mathrm{l}$ TE. Each PCR aliquot was then subjected to the ELISA reaction as above except that detection was performed using each of the four dilutions of the HRP-conjugate. This was done simultaneously for all dilutions and all three color substrates.

Sensitivity of PCR-ELISA. In order to evaluate the sensitivity of PCR-ELISA, two representative isolates of. D. bryoniae RG I (FL2, W95), Phoma (NY21, W97), and D. bryoniae RG II (AZ1, NY16) were chosen. Twenty nanograms, $10 \mathrm{ng}, 1 \mathrm{ng}$, $100 \mathrm{pg}, 10 \mathrm{pg}, 1 \mathrm{pg}$, and $100 \mathrm{fg}$ DNA of each isolate was used as a template for PCR. Ten microliters from each amplified DNA sample was run with gel electrophoresis as before and a further $10 \mu$ of each was detected using the PCR-ELISA technique. Both methods of detection were then compared to evaluate sensitivity. This assay was performed twice.

\section{RESULTS}

ELISA detection of PCR products. Chemical modification of the D. bryoniae and Phoma primers by attachment of biotin and fluorescein to the forward and reverse primers, respectively, did not affect their PCR specificity. For example, 26 isolates of D. bryoniae RG I from South Carolina produced the 650-bp fragment of expected size in a PCR reaction with the modified primer specific for $D$. bryoniae RG I, but 7 Phoma isolates did not react with this primer (Fig. 1). Effective and abundant amplification obtained with the modified 
primers was identical to amplification obtained with unmodified primers as determined visually from agarose gels (28).

Positive ELISA signals for all three groups of organisms were obtained only if the appropriate primer pairs generated PCR products. For example, the $10 \mathrm{NY}$ (Fig. 2A) and 27 SC (data not shown) PCR products of $D$. bryoniae RG I generated using the D. bryoniae RG I-specific primer pair were successfully detected by the ELISA assay. When isolates of Phoma and D. bryoniae RG II were subjected to amplification using the $D$. bryoniae RG I primers, ELISA reactions were negative (Fig. 2A). Similarly, PCR-ELISA successfully detected the seven NY (Fig. 2B) and eight SC (data not shown) Phoma isolates only when amplified with the Phoma primer pair. D. bryoniae RG I and RG II DNA amplified with the Phoma primers yielded negative ELISA reactions (Fig. 2B). Similar results were obtained with 11 of $12 \mathrm{D}$. bryoniae RG II isolates used in this study. For one D. bryoniae RG II isolate, NY14, amplification with the D. bryoniae RG II-specific primer pair resulted in a 500-bp band rather than a 450-bp band which was obtained with the remaining isolates in agarose gels. This was the only isolate that could not be detected using PCR-ELISA. However, the remaining 11 isolates of this genotype that generated the expected 450-bp PCR product were detected successfully (Fig. 2C).

Enzyme concentration. During the course of this study, three different batches of HRP-conjugated monoclonal antifluorescein antibody were used. In all three instances, it was found that a 1:2,000 dilution of the HRP-antibody stock, as supplied by the manufacturer, gave the highest signals (positive reactions) relative to the background (negative reactions). In one test, at a 1:2,000 dilution, TMB produced a $\mathrm{S}: \mathrm{N}$ ratio of $5.7: 1$, OPD, a $\mathrm{S}: \mathrm{N}$ ratio of 7.1:1, and ABTS, a $S: N$ ratio of 7.4:1. A $1: 4,000$ dilution resulted in the HRP being too dilute such that the positive reactions exhibited lower $\mathrm{S}: \mathrm{N}$ ratios (4.6:1, 6.4:1, and 6.9:1, respectively). A 1:500 HRP dilution resulted in an increase in the $S: N$ ratios $(6.4: 1,10.2: 1$, and $17: 1$, respectively). In the negative reactions, there was an unacceptable visible increase in the level of background color of TMB at enzyme dilutions of 1:250 and 1:500, and OPD at a dilution of 1:250. There was no noticeable increase in background of ABTS for any of the negative reactions at any of the dilutions tested.

For any given substrate, the $\mathrm{S}: \mathrm{N}$ ratio fluctuated slightly for the different isolates (Fig. 3). The average S:N ratio with a 1:2,000 dilution of HRP in two independent ELISA tests was 6.8:1, 8.7:1, and 9.4:1 for TMB, OPD, and ABTS, respectively. The average absorbance for all non- $D$. bryoniae RG I isolates was 0.124 with TMB, the substrate used to detect $D$. bry- oniae RG I. Likewise, the average absorbance for all non-Phoma isolates was 0.204 with OPD and 0.111 with ABTS for nonD. bryoniae RG II isolates. Consequently, threshold values for positive reactions were set at 0.200 for TMB and ABTS and 0.350 for OPD.

Termination of color development. The best substrate termination was obtained when color development was arrested with $10 \%$ SDS for TMB and ABTS and with $3 \mathrm{M} \mathrm{H}_{2} \mathrm{SO}_{4}$ for OPD. For the TMB substrate, termination of the color development with $0.5 \mathrm{M} \mathrm{H}_{2} \mathrm{SO}_{4}$ resulted in a $60 \%$ decrease in absorbance while $3 \mathrm{M}$ $\mathrm{H}_{2} \mathrm{SO}_{4}$ resulted in a $72 \%$ decrease in ababsorbance obtained by termination with $10 \%$ SDS. For OPD, 10\% SDS, and $0.5 \mathrm{M}$ $\mathrm{H}_{2} \mathrm{SO}_{4}$ yielded a 63 and $58 \%$ decrease in absorbance at $490 \mathrm{~nm}$, respectively, over 3 $\mathrm{M} \mathrm{H}_{2} \mathrm{SO}_{4}$. Similarly, for ABTS, $10 \%$ SDS and $0.5 \mathrm{M} \mathrm{H}_{2} \mathrm{SO}_{4}$ resulted in a 2 and $19 \%$ reduction in the absorbance at $405 \mathrm{~nm}$, respectively, over $3 \mathrm{M} \mathrm{H}_{2} \mathrm{SO}_{4}$. With one exception, the absorbance values for most substrate/termination reagent combinations normally remained steady or decreased slightly over a 2 -h period as the color faded with time. For the combination of ABTS with $3 \mathrm{M} \mathrm{H}_{2} \mathrm{SO}_{4}$, the absorbance value steadily increased and at the end of 2 sorbance at $405 \mathrm{~nm}$ when compared to the

$\mathrm{h}$ was actually $31 \%$ higher than the starting value.

Crude fungal extracts. In a "blind" test of 10 unknown fungal samples (Table 1), PCR-ELISA identified five isolates as $D$. bryoniae RG I, one isolate as $D$. bryoniae RG II, and one isolate as Phoma. The remaining three isolates produced negative ELISA reactions. The identity of all 10 isolates was confirmed independently by examining colony and spore morphologies The three isolates that did not react with the PCR-ELISA primers did not belong to any of the fungal groups used in this study. The average $\mathrm{S}: \mathrm{N}$ ratios of the ELISA were 2.8:1 for TMB, 3.7:1 for OPD, and 8:1 for ABTS. Although the $S: N$ ratios were lower than for pure DNA, the results were still very clear, and a reliable identification could be made from visual analysis of the ELISA assay alone. Again, results of the ELISA assay were consistent with the results obtained by gel electrophoresis.

Sensitivity of PCR-ELISA. On agarose gels, PCR products amplified from a minimum of $100 \mathrm{pg}$ of $D$. bryoniae RG I template DNA were readily visible, whereas for the Phoma and D. bryoniae RG II isolates that were tested, DNA amplified from a minimum of $10 \mathrm{pg}$ template were readily visible. For the ELISA assay, amplification from a minimum of $10 \mathrm{ng}$ of

\section{$\begin{array}{llllllllllllllllllll}M & 1 & 2 & 3 & 4 & 5 & 6 & 7 & 8 & 9 & 10 & 11 & 12 & 13 & 14 & 15 & 16 & 17 & 18 & 19\end{array}$}

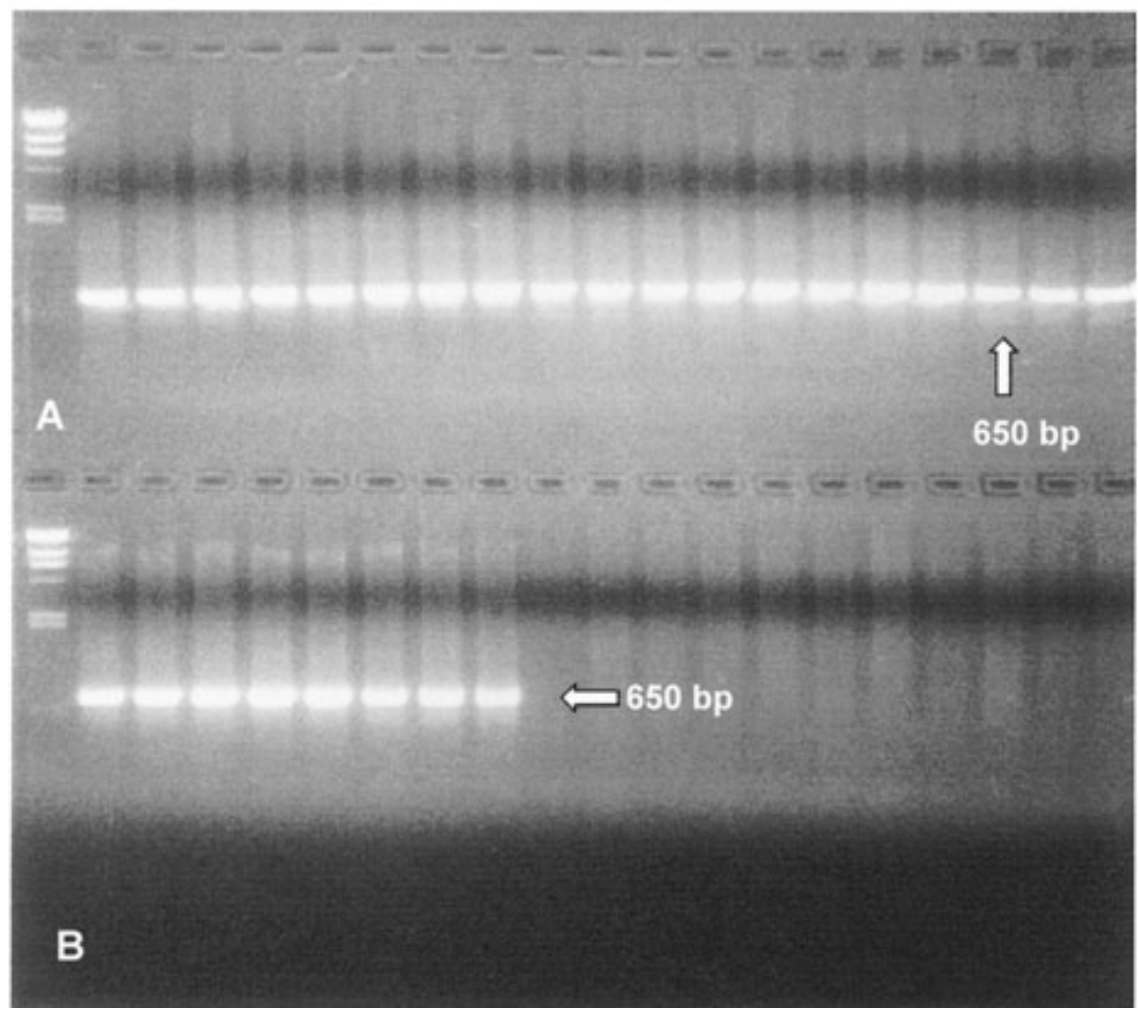

Fig. 1. DNA of 26 Didymella bryoniae RG I isolates (lanes A2 to A19 and B1 to B8), and seven Phoma isolates (lanes B11 to B17) from the South Carolina collection amplified with the D. bryoniae-specific primers. D. bryoniae RG I FL2 (lane A1), Phoma NY21 (lane B10), and D. bryoniae RG II AZ1 and NY16 (lanes B18 and B19, respectively) were from the New York collection and were used as internal controls. Lane B9 contained no template DNA. M:lambda/HindIII molecular size marker. 
D. bryoniae RG I template DNA gave a strong signal that could be detected visually above the background. Although the ELISA reader could detect DNA amplified from as little as $1 \mathrm{ng}$ of $D$. bryoniae template, this reaction was difficult to distinguish from the background by eye alone. For the Phoma and D. bryoniae RG II samples, DNA amplified from a minimum of $1 \mathrm{ng}$ of template was easily visualized above background for the ELISA assay. The ELISA reader could detect DNA amplified from $100 \mathrm{pg}$ of $D$. bryoniae RG II template.

\section{DISCUSSION}

PCR-ELISA was used successfully to detect D. bryoniae and Phoma sp. For all isolates tested here, positive ELISA signals were obtained only for those isolates that produced a PCR fragment of the expected size. Thus, PCR-ELISA retained the specificity that was obtained with the previous PCR assay $(9,30,32)$. This technique can be used further to differentiate $D$. bryoniae from nonpathogenic or weakly virulent Phoma isolates $(8,40)$. Although the $D$. bryoniae-specific PCR primers and the associated ELISA assay are precise enough to reliably detect $D$. bryoniae, the Phomaspecific primer can be used to identify other isolates that do not produce a signal with the D. bryoniae primers (40). Thus, PCR-ELISA could be used to identify several different Phoma-like fungi that have been recovered from cucurbit seedlots (7).

In a previous study, all Phoma isolates inoculated onto watermelon and cantaloupe seedlings were nonpathogenic, although they infected some of the seedlings (8). However, a Phoma isolate included in the present study (NC2) was pathogenic on cucumber in greenhouse tests (identified as DB-H-23) (34). A Phoma sp. also has been isolated from watermelon seed and lesions on watermelon seedlings (7). It is possible that environmental or host factors influence whether disease develops when Phoma spp. infect cucurbits. Because of the possibility that some of these isolates are pathogenic, the Phoma-specific primer used in the present study may be useful in some situations to detect or identify Phoma.

Variation in virulence among $D$. bryoniae isolates has been documented $(2,8,34,38,40)$. In our previous study, 2 of 19 isolates of $D$. bryoniae were weakly virulent on watermelon and cantaloupe seedlings (8). Although disease severity for these two isolates was not statistically greater than the noninoculated control, both isolates produced a few lesions on several plants. The potential for damage to a crop by seedborne $D$. bryoniae is sufficient to label any occurrence of D. bryoniae a positive test result regardless of the degree of virulence of the particular isolate (12).

With one exception, results with PCRELISA were $100 \%$ equivalent to those obtained with PCR and gel electrophoresis. Once the critical assay parameters were optimized, no false positives or negatives were obtained. The only PCR-ELISA reaction that differed from the gel electrophoresis analysis was that of $D$. bryoniae RG
II NY14. Although this isolate yielded a 500-bp PCR band that was visible in agarose gels, PCR-ELISA failed to detect this product. This suggests that the PCR fragment was a product of only one primer that primed the template DNA twice, similar to that of a RAPD reaction, although this product was not sequenced. This implies that the DNA fragment generated for NY14 was a nontarget PCR product. In this case, incorporation of different binding moieties to the two primers aided in increasing the specificity of the PCR-ELISA. An advantage of the ELISA over gel electrophoresis is that PCR-ELISA can be used for discriminating between target (specific) and nontarget (nonspecific) fragments of the same size, if the nontarget product results from amplification with a single primer. A nontarget fragment of the same size as a positive control, i.e., a false positive, if assayed in an agarose gel, could potentially contribute to misidentification of the sample.

PCR-ELISA correctly identified 10 unknown fungal isolates from crude fungal extracts: six of six isolates as $D$. bryoniae, one isolate as Phoma, and three isolates that were neither D. bryoniae nor Phoma that did not react with any primer. The S:N ratios generally were lower for crude extracts than for pure DNA. This was not surprising since fewer template DNA particles were obtained during extract preparation as measured with a fluorometer and therefore, less PCR product was expected. However, positive reactions could be distinguished easily from negative reactions and from the background. Even the lightest

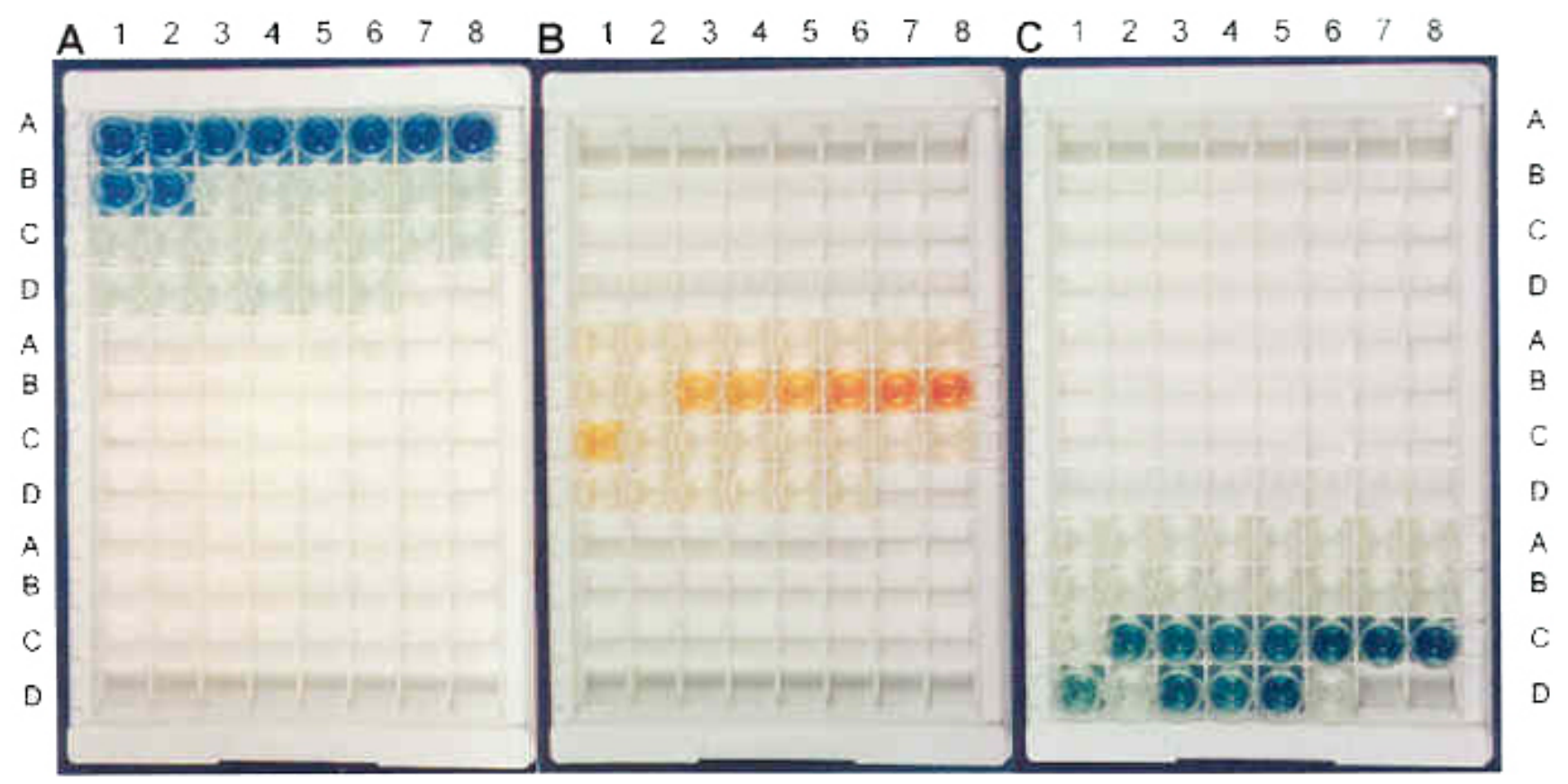

Fig. 2. Polymerase chain reaction enzyme-linked immunosorbent assay (PCR-ELISA) of 27 isolates from the New York collection after amplification with the A, Didymella bryoniae RG I-specific, B, Phoma-specific, and C, D. bryoniae RG II-specific primers. Isolates in plates A, B, and C are identical. D. bryoniae RG I, wells A1-A8 and B1-B2; Phoma, wells B3-B8 and C1; and D. bryoniae, RG II, wells C2-C8 and D1-D5. D. bryoniae RG I W95 (B2) and Phoma W97 (B5) from the South Carolina collection were used as internal controls. Well D6 contained no template DNA. Well D2 contained isolate NY14. 
staining PCR product produced an ELISA signal distinct from the negative reactions. This verifies that the use of crude fungal extracts is a very quick and effective technique for simultaneously assaying multiple samples. Using mycelium growing on filter paper would be directly applicable to identifying Phoma-like fungi that grow from cucurbit seeds in standard blotter assays to detect seed contamination by $D$. bryoniae (5).

In previous reports, PCR-ELISA was found to be more sensitive than agarose gel electrophoresis $(4,22)$. In this study, the ELISA detection was found to be less sensitive than detection in agarose gels. With the $D$. bryoniae RG I primer, gel detection was at least 10 times more sensitive than PCR-ELISA, whereas for the D. bryoniae RG II and Phoma isolates, gel detection was at least 100 times more sensitive. In this study, we were not trying to increase the sensitivity of detection, but rather evaluating PCR-ELISA as an alternative rapid detection procedure. Since we could detect DNA amplified from a minimum of 1 ng template DNA, which was the threshold obtained when isolating crude fungal DNA, the detection limits of the ELISA were adequate. If required, using chemiluminescence ELISA would increase the sensitivity of the ELISA reaction (26).

Prior to optimization of the color development protocol, TMB was the most sensitive of the three substrates used in this study. However, false positive signals were consistently observed in wells that contained no template DNA but had been sub- jected to PCR. We concluded that primerdimer artifacts were being detected as has been reported (10). In contrast, in agarose gels, primer-dimers were not visible because they appeared to be in very low concentrations. One alternative was to reduce the amount of primers used during PCR, but this led to variations in the color intensities during the ELISA detection. Another alternative was to perform nested PCR that would have reduced the primer-dimer concentrations (10). This would have meant that two separate PCR reactions had to be done, resulting in an increase in time, materials, and cost. Therefore, in this study, the sensitivity of TMB was reduced by decreasing the $\mathrm{H}_{2} \mathrm{O}_{2}$ concentration, which drove the color reaction to the point where primer-dimer artifacts were no longer detectable. Unfortunately, since TMB was used for the $D$. bryoniae primers, this reduced the sensitivity of the ELISA reaction below that of agarose gels. However, results were still acceptable.

After optimization of the ELISA reaction, the most sensitive substrate was ABTS, which produced a dark green color. Signal to noise ratios for ABTS were always higher than TMB and OPD, irrespective of whether purified fungal DNA or crude fungal extracts were used. ABTS also had the lowest background and therefore, results were always the clearest and easiest to read, even at high (1:250 dilution) HRP-conjugate concentrations. OPD was less sensitive, and had a higher background because of higher sensitivity to light and instability of the chromogen (23).
The orange color of OPD was sometimes difficult to distinguish from the light yellow background of negative reactions. The least sensitive substrate was TMB, which also had a high background. However, results with TMB were easier to evaluate than OPD because of the clearer differences between the dark blue of positive reactions and the light blue of negative ones (Fig. 2). Under the conditions of this assay, ABTS with SDS as the terminating reagent consistently produced the best results and is the substrate combination of choice for any future work.

Although DIECA was originally tested in ELISA assays when using crude preparations of plant sap $(17,25)$, this study determined that it was also essential when using crude fungal extracts. Failure to use DIECA caused the ELISA reaction to fail because HRP-conjugate is sensitive to trace amounts of inhibitors, such as azide, (21) that may have been present in crude preparations. The TPS buffer used for preparation of fungal extracts was capable of neutralizing PCR inhibitors such as phenolic compounds (32) and polysaccharides (24), but was incapable of sufficiently neutralizing inhibitors to the ELISA reaction.

Based on the results obtained here, PCR-ELISA provided a highly specific, yet simple, effective, inexpensive, and convenient assay for detection and differentiation of D. bryoniae RG I and RG II and Phoma isolates. Crude fungal DNA extracts were used successfully, thereby making the test extremely rapid, since this obviates the

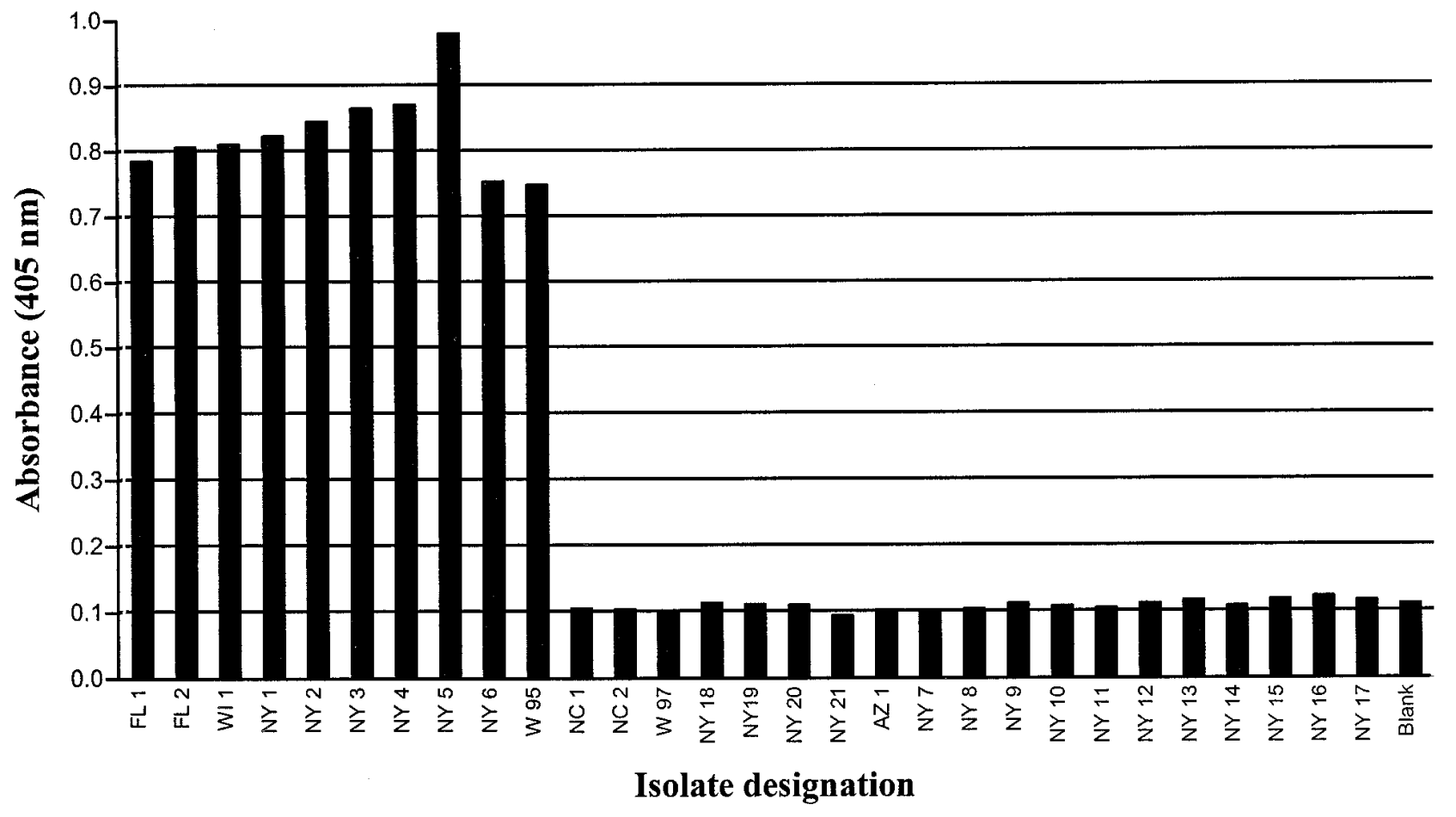

Fig. 3. Polymerase chain reaction enzyme-linked immunosorbent assay (PCR-ELISA) absorbance values for PCR amplification of 29 isolates with the Didymella bryoniae RG I-specific primers. New York collection of D. bryoniae RG I (first nine bars), Phoma (bars 11, 12, 14 through 17), and D. bryoniae RG II (bars 18 through 29) isolates show relative signal:noise ratios. D. bryoniae RG I W95 (bar 10) and Phoma W97 (bar 13) are internal controls from the South Carolina collection. Blank (bar 30) contained no template DNA. 
need to isolate pure DNA. After PCR, the samples were simply treated as a routine ELISA assay. In the future, all reagents could be assembled and made available in kit form. Alternatively, the procedure could easily be automated for screening multiple samples. Hazardous chemicals associated with gel electrophoresis were eliminated, which increased operator safety and reduced toxic environmental waste.

\section{ACKNOWLEDGMENTS}

We thank S. W. Scott and T. Zimmerman, Clemson University, for assistance with ELISA; and T. A. Zitter, Cornell University, and G. P. Hoyos, Syngenta Seeds, Inc., for providing cultures. This study was supported by NRICGP Strengthening Award 96-35311-3631 to A. P. Keinath, Hatch project SC01628, and a Fulbright Fellowship to B. M. Somai.

\section{LITERATURE CITED}

1. Chiu, W. F., and Walker, J. C. 1949. Morphology and variability of the cucurbit black rot fungus. J. Agric. Res. 78:81-102.

2. Chiu, W. F., and Walker, J. C. 1949. Physiology and pathogenicity of the cucurbit blackrot fungus. J. Agric. Res. 78:589-615.

3. Gale, K. R., Dimmock, C. M., Gartside, M., and Leatch, G. 1996. Anaplasma marginale: Detection of carrier cattle by PCR-ELISA. Int. J. Parasitol. 26:1103-1109.

4. Hartung, J. S., Pruvost, O. P., Villemot, I., and Alvarez, A. 1996. Rapid and sensitive colorimetric detection of Xanthomonas axonopodis pv. citri by immunocapture and a nested polymerase chain reaction assay. Phytopathology 86:95-101.

5. International Seed Testing Association. 1976. International rules for seed testing. Seed Sci. Technol. 4:3-49.

6. Jenkins, S. F., Jr., and Person, L. H. 1973. Ascochyta blight of cucurbits caused by Ascochyta phaseolorum. (Abstr.) Phytopathology 63:444.

7. Keinath, A. P. 1996. Spread of Didymella bryoniae from contaminated watermelon seed and transplants in greenhouse and field environments. Pages 65-72 in: Recent Research Developments in Plant Pathology, Vol. 1, S. G. Pandalai, ed. Research Signpost, Trivandrum, India.

8. Keinath, A. P., Farnham, M. W., and Zitter, T. A. 1995. Morphological, pathological and genetic differentiation of Didymella bryoniae and Phoma spp. isolated from cucurbits. Phytopathology 85:364-369.

9. Keinath, A. P., Somai, B. M., and Dean, R. A. 2001. Method of diagnosing gummy stem blight in plants using a polymerase chain reasction assay. U.S. Patent 6,258,537 B1.

10. Kemp, D. J., Smith, D. B., Foote, S. J., Samaras, N., and Peterson, M. G. 1989. Colorimetric detection of specific DNA segments amplified by polymerase chain reactions. Proc. Natl. Acad. Sci. USA 86:2423-2427.
11. Koike, S. T. 1997. First report of gummy stem blight, caused by Didymella bryoniae, on watermelon transplants in California. Plant Dis. 81:1331.

12. Lee, D.-H., Mathur, S. B., and Neergard, P. 1984. Detection and location of seed-borne inoculum of Didymella bryoniae and its transmission in seedlings of cucumber and pumpkin. Phytopathol. Z. 109:301-308.

13. Lee, S. B., Milgroom, M. G., and Taylor, J. W. 1988. A rapid, high yield mini-prep method for isolation of total genomic DNA from fungi. Fungal Genet. Newsl. 35:23-24.

14. Luk, J. M., Kongmuang, U., Tsang, R. S. W., and Lindberg, A. A. 1997. An enzyme-linked immunosorbent assay to detect PCR products of the $r f b S$ gene from serogroup D Salmonellae: a rapid screening prototype. J. Clin. Microbiol. 35:714-718.

15. Maiero, M., Bean, G. A., and Ng, T. J. 1991. Toxin production by Alternaria solani and its related phytotoxicity to tomato breeding lines. Phytopathology 81:1030-1033.

16. Maramatsu, Y., Yanase, T., Okabayashi, T., Ueno, H., and Morita, C. 1997. Detection of Coxiella burnetii in cow's milk by PCRenzyme-linked immunosorbent assay combined with a novel sample preparation method. Appl. Environ. Microbiol. 63:21422146.

17. McLaughlin, M. R., Barnett, O. W., Gibson, P. B., and Burrows, P. M. 1984. Enzyme-linked immunosorbent assay of viruses infecting forage legumes. Phytopathology 74:965-969.

18. Mutasa, E., Chwarszczynska, D., and Asher, M. 1996. Single-tube, nested PCR for the diagnosis of Polymyxa betae infection in sugar beet roots and colorimetric analysis of amplified products. Phytopathology 86:493497.

19. Norton, J. D., and Cosper, R. D. 1989. AC-70154 , a gummy stem blight resistant muskmelon breeding line. Hortscience 24:709-711.

20. Norton, J. D., Cosper, R. D., Smith, D. A., and Rymal, K. S. 1986. AU-Jubilant and AUProducer watermelons. Hortscience 21:14601461.

21. Persijn, J. P., and Jonker, K. M. 1978. A terminating reagent for the peroxidase-labeled enzyme immunoassay. J. Clin. Chem. Clin. Biochem. 16:531-532.

22. Pollini, C. P., Giunchedi, L., and Bissani, R. 1997. Immunoenzymatic detection of PCR products for the identification of phytoplasmas in plants. J. Phytopathol. 145:371-374.

23. Porstmann, B., Porstmann, T., and Nugel E. 1981. Comparison of chromogens for the determination of horseradish peroxidase as a marker in enzyme immunoassay. J. Clin. Chem. Clin. Biochem. 19:435-439.

24. Raina, K., and Chandlee, J. M. 1996. Recovery of genomic DNA from a fungus (Sclerotinia homoeocarpa) with high polysaccharide content. Biotechniques 21:1030-1032.

25. Reddick, B. B., and Barnett, O. W. 1983. A comparison of three potyviruses by direct hybridization analysis. Phytopathology 73:15061510.
26. Schmid, J. A., and Billich, A. 1997. Simple method for high sensitivity chemiluminescence ELISA using conventional laboratory equipment. Biotechniques 22:278-280.

27. Shindo, M., Di Biseeglie, A. M., Silver, J., Limjoco, T., Hoofnagle, J. H., and Feinstone, S. M. 1994. Detection and quantitation of hepatitis $\mathrm{C}$ virus RNA in serum using the polymerase chain reaction and a colorimetric enzymatic detection system. J. Virol. Methods 48:65-72

28. Sitterly, W. R. 1972. Breeding for disease resistance in cucurbits. Annu. Rev. Phytopathol. 10:471-490.

29. Sitterly, W. R., and Keinath, A. P. 1996. Gummy stem blight. Pages 27-28 in: Compendium of Cucurbit Diseases. T. A. Zitter, D. L. Hopkins and C. E. Thomas, eds. American Phytopathological Society, St. Paul, MN.

30. Somai, B. M. 1998. PCR detection, differentiation and characterization of Didymella bryoniae and related Phoma species. Ph.D. diss. Clemson University, Clemson, SC.

31. Somai, B. M., Dean, R. A., Farnham, M. W. Zitter, T. A., and Keinath, A. P., 2002. Internal Transcribed Spacer Region 1 and 2 and Random Amplified Polymorphic DNA analysis of Didymella bryoniae and related Phoma species isolated from cucurbits. Phytopathology. (In press.)

32. Somai, B. M., Keinath, A. P., Dean, R. A Zitter, T. A., and Farnham, M. W. 1997. PCR identification and differentiation of Didymella bryoniae and Phoma species. (Abstr.) Phytopathology 87:S92.

33. St. Amand, P. C., and Wehner, T. C. 1991 Crop losses to 14 diseases of cucumber in North Carolina from 1983-1988. Cucurbit Genet. Coop. Rpt. 14:15-17.

34. St. Amand, P. C., and Wehner, T. C. 1995. Eight isolates of Didymella bryoniae from geographically diverse areas exhibit variation in virulence but no isolate by cultivar interaction on Cucumis sativus. Plant Dis. 79:11361139

35. Sumner, D. R., and Phatak, S. C. 1987. Control of foliar diseases of cucumber with resistant cultivars and fungicides. Appl. Agric Res. 2:324-329.

36. Thomson, D. and Henry, R. 1995. Single-step protocol for preparation of plant tissue for analysis by PCR. Biotechniques 19:394-400.

37. van der Vliet, G. M. E., Hermans, C. J., and Klatser, P. R. 1993. Simple colorimetric microtiter plate hybridization assay for detection of amplified Mycobactertium leprae DNA. J. Clin. Microbiol. 31:665-670.

38. van Steekelenburg N. A. M. 1982. Factors influencing external fruit rot of cucumber caused by Didymella bryoniae. Neth. J. Plant Pathol. 88:47-56.

39. Wiant, J. S. 1945. Mycosphaerella black rot of cucurbits. J. Agric. Res. 71:193-213.

40. Zuniga, T. L. 1999. Gummy stem blight (Didymella bryoniae) of cucurbits: Pathogen characterization and inheritance of resistance in melon (Cucumis melo). Ph.D. diss. Cornell University, Ithaca, NY. 